\title{
BASIC GRADUATE CURRICULA OF GIS DESIGN IN BEIJING NORMAL UNIVERSITY, CHINA
}

\author{
Huiping Liu \\ State key laboratory of remote sensing science; Beijing key laboratory of environmental remote sensing and digital city, \\ School of Geography, Beijing Normal University, Beijing, China, hpliu@bnu.edu.cn
}

\author{
Commission VI, WG VI/4
}

KEY WORDS: Basic graduate curricula design, Body knowledge, Practice exercises design

\begin{abstract}
:
As the basic course of postgraduate programme in Beijing Normal University, the Introduction of GIS\&T is selected by almost all the students of the GIS specialty and other related specialties like physical and human geography, ecology, environmental science and so on. The number of the students dropped in the course was over 100 each year in the past 5 years. The background of education and demands of the students were very different. How to design the course of Introduction of GIS\&T to meet the demands of students is important. This paper include following parts: (1) The analysis of student's difference and the structure design of the course, (2) Spatial thinking and the body of knowledge design, (3) The practice exercises design, and (4)Feedback and evaluating
\end{abstract}

\section{INTRODUCTION}

The course of "Introduction of GIS\&T" is the basic curricula in the postgraduate education of Beijing Normal University. It is selected by almost all the students of the GIS specialty and other related specialties every year. The number of the students dropped in the course was over 100 each year in the past 5 years. The background of education and demands of the students were very different. The design of the course appears important to meet the demands of students and the goal of education.

The discussions about the GIS\&T education are increased rapidly these years (Marco Painho, 2012). The studies on the design of the curriculum showed to stress on body knowledge, learning cycles, professional education and so on (Steven D. Prager, 2012, Kenneth Foote, 2012). The research on spatial thinking was also discussed (Committee on support for thinking spatially, 2006).

This paper is to introduce the design of the basic curricula of postgraduate of Beijing Normal University, China. The design of the course includes the structure design, body knowledge and laboratory exercises, and practice exercises design.

\section{THE DIFFERENCE STUDENTS AND THE STRUCTURE DESIGN OF THE COURSE}

The analysis of the difference of student is based on the education background and specialties. The student was from 16 specialties, 9 schools in the university (Fehler! Verweisquelle konnte nicht gefunden werden.). There were about 100 students attend the course of Introduction of GIS\&T, and 83 students get the credit of the course. About $84 \%$ students take the course as the basic course and $16 \%$ of them take the course as specialty elective course. There were $30 \%$ of them having good GIS education, take the course as introductory course and have other courses related to GIS during their postgraduate period. $65 \%$ of the students have the basic knowledge and take the course as the whole study of GIS, and 5\% of them with no knowledge of GIS and also take the course as the whole study.
The goal of the course is to increase expectations with regard to knowledge dimension and cognitive levels, to deeper understand of GIS\&T theory, and to improve the ability of solving application problems using GIS.

As the basic curricula, the theory of GIS\&T and the ways of solving geographical problems are the bases of post graduated program of geosciences and environmental science. Most of students (about 70\%) will not do further reach work on GIS theory or technology, and will applied the idea or methods to their specialty reach. They need to know the basic theory and application methods of GIS which include the operations of the GIS software.

To satisfy the demands of students and to reach the goal of the course, the course is then designed to include the main theory of GIS, laboratory exercises and practice exercises, and the time arrange of the three parts is about 5:3:2. There are about 27 class hours for theory of GIS and about 16 class hours for laboratory exercises which is arranged after each main theory course. The practice exercises are for 11 class hours.

\section{SPATIAL THINKING AND THE BODY OF KNOWLEDGE DESIGN}

Taking the spatial thinking as the key component of GIS education, the body of knowledge of the course is arranged as three major parts--the nature of space, methods of representation of spatial information, and processes of spatial seasoning. The laboratory exercises to each part of the knowledge are also arranged synchronously.

In the spatial analysis theory teaching of the course, eight laboratory exercises are designed and arranged according to different curriculum content and degree of difficulty (Table 1). Eight GIS software operations by which practice teaching system of constitutes progressive approach can be constituted. We use two current mainstream GIS professional software in the experiments: "ArcGIS"C E ERI, Inc. Copyright and "SuperMap"@ SUPERMAP, Ctd. Copyright. In the former six experiments, basic operations and spatial analysis methods of 


\begin{tabular}{|l|c|c|}
\hline \multicolumn{1}{|c|}{ Specialties } & Students Number & Percentage \\
\hline GIS & 26 & 21.33 \\
\hline Physical geography & 19 & 19.28 \\
\hline Human geography & 16 & 4.82 \\
\hline Land and resources management & 4 & 4.82 \\
\hline Hydrology and water resources & 4 & 2.41 \\
\hline Environmental sciences & 2 & 2.41 \\
\hline Water conservancy and Hydropower Engineering & 2 & 2.41 \\
\hline Water information & 2 & 1.20 \\
\hline Regional economies & 1 & 1.20 \\
\hline Conservation of water and soil & 1 & 1.20 \\
\hline Geographical teaching & 1 & 1.20 \\
\hline Environment engineering & 1 & 1.20 \\
\hline Natural resources & 1 & 1.20 \\
\hline Hydraulics and river dynamics & 1 & 1.20 \\
\hline Disaster prevention and Mitigation Engineering & 1 & 1.20 \\
\hline Remote sensing science and Application & 1 & 100.00 \\
\hline
\end{tabular}

Table 1 . The specialties of the students

the most widely used international software "ArcGIS" are introduced, including the basic framework of software, spatial data collection and compiling, the establishment of spatial topological relations, vector and raster data spatial analysis methods and how to use "Model Builder" modules. In the latter two experiments, the data organization format, spatial visualization, image registration and basic spatial analysis procedures of the largest China software "SuperMap" are described. These eight practices are enable students to deepen the understanding of GIS spatial analysis connotations at each step of theoretical knowledge learning in the classroom.
Students have the handbook of laboratory exercises which includes (1) the operations of the example steps by steps and (2) the homework which is quite similar to the example. The handbook of laboratory exercises helps student a lot to deal with the hard works of GIS software operations. The disadvantage is that the handbook let the operations too easy to follow and too easy to be forget. The students could feel hard to or even could not use the software without the handbook. To strengthen practice skill of GIS, the practice exercises were designed.

\begin{tabular}{|l|l|l|}
\hline \multirow{5}{*}{ Basic Function } & Laboratory Exercises & \multicolumn{1}{c|}{ Contents } \\
\hline & $\begin{array}{l}\text { Exercises 1. } \\
\text { Get to know GIS software }\end{array}$ & $\begin{array}{l}\text { Introduction of ArcGIS software components,to convert map elements } \\
\text { into points, lines, polygons and to accomplish simple data collection } \\
\text { and property editing. }\end{array}$ \\
\cline { 2 - 3 } & $\begin{array}{l}\text { Exercises 2. } \\
\text { data operations }\end{array}$ & $\begin{array}{l}\text { The geometry modification and attribute table operations of vector } \\
\text { data, coordinate system determination and topological relations } \\
\text { establishment }\end{array}$ \\
\cline { 2 - 3 } & $\begin{array}{l}\text { Exercises 3. } \\
\text { GIS thematic map production }\end{array}$ & $\begin{array}{l}\text { Symbolized and labeled with the data layers, and the other is to add } \\
\text { elements to thematic maps }\end{array}$ \\
\hline \multirow{5}{*}{ Spatial Analysis } & $\begin{array}{l}\text { Exercises 4. } \\
\text { vector data space analysis }\end{array}$ & $\begin{array}{l}\text { Network analysis and Contour switch to TIN format } \\
\text { methods,Buffering }\end{array}$ \\
\cline { 2 - 3 } & $\begin{array}{l}\text { Exercises 5. } \\
\text { raster data spatial analysis }\end{array}$ & $\begin{array}{l}\text { Distance cartographic, the cost and } \\
\text { distance-weighted, data re-classification and multi-level merging. }\end{array}$ \\
\cline { 2 - 3 } & $\begin{array}{l}\text { Exercises 6. } \\
\text { Model Builder }\end{array}$ & $\begin{array}{l}\text { Practice how GIS workflow is achieved byModel Builder deeply } \\
\text { understand the connotation of visual editing module in "ArcGIS", } \\
\text { deeply understand the connotation of visual editing language and the } \\
\text { character of GIS workflows by creating, editing and managing GIS } \\
\text { model. }\end{array}$ \\
\hline Software \\
comparison
\end{tabular}

Table 1 Laboratory Exercises of the course

\section{THE PRACTICE EXERCISES DESIGN}

The practice exercise is the application project. The practice exercises are finished by students without guide or handbook. The education goal of it is to develop the application ability of
GIS which include two aspects: (1) understanding the application problems and (2) solving the problems by GIS methods. 
Each practice exercise includes one application problem, a set of map data and a readme file of demands. There are over 80 different projects be prepared for the course exercises. Students are divided into groups to finish one project independently. Each group includes 2-3 students. The experimental requirements are as follows:

- Input maps by digitizing according to the readme file. Every student should input one or two maps and one group should input 3 to 6 maps.

- Analysis the application problem of the project and try to find more spatial data from internet.

- Establish the objectives and criteria for the analysis.

- Prepare the data for spatial operations.

- Perform the spatial operations.

- Prepare the derived data for tabular analysis.

- Evaluate the interpret of the results.

The report of the exercise should be written by the groups. The data of results and the interim results of each step should be handed in.

\section{FEEDBACK AND EVALUATING}

The final score of the course is assessed comprehensively according to the results of the eight lab exercise and reports of the practice exercise. The proportion of two parts accounted for $30 \%$ and $70 \%$. This scoring system will enable students to completely melt theoretical knowledge into practice operation. It is not only reflects the students' mastery of the knowledge, but also respect for individual differences of students. So the just and scientific of the score can be ensured.

The practice exercise also includes several topic seminars. The purpose of the seminar is to present the report of the exercise, question answering and the discussion of the topic application. The report should be submitted before seminar. After answering all the questions, students modify their work and reports according to advices from other students in the seminar. The new report could be submitted again. The score of the practice exercise include two reports' score and seminar score.

\section{REFERENCES}

Painho, M., Curvelo, P., 2012. Building dynamic, ontologybased alternative paths for GIS\&T curricula, Teaching Geographic Information Science and Technology in Higher Education, 2012, Wiley-Blackwell press, Singapore, pp 97-115

Prager, S. D., 2012. Using the GIS\&T body of knowledge for curriculum design: different design for different contexts, Teaching Geographic Information Science and Technology in Higher Education, 2012, Wiley-Blackwell press, Singapore, pp 63-80

Footes, K. E., 2012. Scope and sequence in GIS\&T education: learning theory, learning cycles and spiral curricula, Teaching Geographic Information Science and Technology in Higher Education, 2012, Wiley-Blackwell press, Singapore, pp81-96

Committee on the support for the thinking spatially, Learning to think spatially, 2006. GIS as a support system in the K-12 curriculum, 2006, The National Academies Press, Washington D. C., pp 25-438 